\title{
Treasured Possessions
}




\section{OBJECTS/HISTORIES}

Critical Perspectives on Art, Material Culture, and Representation

A series edited by Nicholas Thomas

PUBLISHED WITH THE ASSISTANCE

OF THE GETTY FOUNDATION 


\section{Haidy \\ Geismar}

Duke UNIVERSITY PRESS

\section{Treasured Possessions}

INDIGENOUS INTERVENTIONS

INTO CULTURAL AND

INTELLECTUAL PROPERTY

DURHAM AND LONDON 2013 
(C) 2013 Duke University Press

All rights reserved

Printed in the United States of America on acid-free paper $\infty$ Interior design by Bea Jackson. Cover design by Jennifer Hill. Typeset in Garamond Premier Pro.

Library of Congress Cataloging-in-Publication Data Geismar, Haidy.

Treasured possessions : indigenous interventions into cultural and intellectual property / Haidy Geismar.

pages $\mathrm{cm}$ - (Objects/histories : critical perspectives on art, material culture, and representation) Includes bibliographical references and index. ISBN 978-0-8223-5412-3 (cloth : alk. paper) ISBN 978-0-8223-5427-7 (pbk. : alk. paper)

1. Cultural property-Vanuatu. 2. Intellectual property-Vanuatu. 3. Cultural property-New Zealand. 4. Intellectual property-New Zealand. 5. Ni-Vanuatu. 6. Maori (New Zealand people). I. Title. II. Series: Objects/histories.

DU760.G455 2013

993'.00499442-dc23 2013004647

Duke University Press gratefully acknowledges the support of the Humanities Initiative of New York University that provided funds, through its Grants-in-Aid program, toward the publication of this book.

This work is licensed under the Creative Commons AttributionNonCommercial-NoDerivs 3.0 Unported License. To view a copy of this license, visit http://creativecommons.org/licenses/by-nc-nd/3.0/ or send a letter to Creative Commons, 444 Castro Street, Suite 900, Mountain View, California 94041, USA. “Noncommercial” as defined in this license specifically excludes any sale of this work or any portion thereof for money, even if the sale does not result in a profit by the seller or if the sale is by a 501 (c) (3) nonprofit or NGO. 